\title{
Sobre voos, sopros e vozes: a "(anti)gênesis" poética de Orides Fontela
}

\author{
About Flights, Blows and Voices: The Orides Fontela's Poetic "(Anti)genesis" \\ Sobre vuelos, soplos y voces: la "(anti)génesis" poética de Orides Fontela \\ Nathaly Felipe Ferreira Alves*
}

\section{Resumo}

Este trabalho tem por objetivo analisar o estatuto ontológico da linguagem poética, fundamentada por um ritmo singular, a partir da apreciação de dois poemas de Orides Fontela: "Gênesis", publicado em Helianto, de 1973; e "Antigênesis", em Rosácea, de 1986. Para tanto, lançaremos mão das considerações de Henri Meschonnic (2006) e de Paul Valéry (2007) no que diz respeito à formalização dos poemas enquanto objetos escriturais genuinamente críticos da linguagem, de si mesmos e do mundo.

Palavras-chave: Orides Fontela, crítica poética, linguagem poética, ritmo.

\begin{abstract}
This work aims to analyze the ontological status of poetic language, underpinned by a particular rhythm, based on the appreciation of two poems written by Orides Fontela: "Gênesis" (Helianto, 1973) and "Antigênesis" (Rosácea, 1986). Therefore, we will use Henri Meschonnic (2006) and Paul Valéry (2007) considerations concerning the formalization of poems as genuinely critical, scriptural objects of language, of themselves and of the world.
\end{abstract}

Keywords: Orides Fontela, poetic criticism, poetic language, rhythm.

\section{Resumen}

Este trabajo tiene por objetivo analizar el estatuto ontológico del lenguaje poético, fundamentado por un ritmo singular, a partir de la apreciación de dos poemas de Orides Fontela: "Génesis" (Helianto, 1973) y "Antigénesis" (Rosácea, 1986). Para ese fin, recurrimos a las consideraciones de Henri Meschonnic (2006) y de Paul Valéry (2007), en lo que respecta a la formalización de los poemas como objetos escriturales genuinamente críticos del lenguaje, de sí mismos y del mundo.

Palabras-clave: Orides Fontela, crítica poética, lenguaje poético, ritmo.

\author{
Ó rio \\ subterrâneo ao ritmo \\ do sangue
}

Orides Fontela, em “Letes"

Este trabalho revela-se como esboço de reflexão que privilegia sondar, em certa medida, o estatuto ontológico da linguagem que se fundamenta, segundo argumentaremos, à luz do pensamento de Henri Meschonnic (2006), em Linguagem ritmo e vida, na própria realização da escrita poética, crítica e ontológica por excelência. Partimos do pressuposto que, sob a égide de um ritmo singular, encarnado sinuosamente em uma espécie de "voz-silêncio" 1 vislumbrada em dois poemas de Orides Fontela - "Gênesis", compilado no livro Helianto, de 1973, e "Antigênesis", texto de Rosácea, obra publicada em 1986 -, desvela-se a instauração de um ato criativo que remete às origens do mundo e, concomitantemente, à aurora da própria linguagem. Devido à questão da voz,

\footnotetext{
* Universidade Estadual de Campinas (Unicamp), Campinas, SP, Brasil. Bolsista Fapesp (Processo n 2018/22189-1). (Dorcid.org/0000-0002-7555-5954. E-mail: nathalyffalves@gmail.com

${ }^{1}$ De acordo com Meschonnic (2006, p. 38): “[...] há voz no silêncio e silêncio na voz. Há sempre sentido. Ou, sobretudo, há significação. Pois, para a linguagem, não existe fora da linguagem. Os silêncios fazem parte dela. Aliás, nós os fazemos falar”.
} 
problematizada em certa crítica especializada sobre a obra de Orides, em que o expediente do silêncio ${ }^{2}$ ganha destaque, faz parte de nossas indagações recuperar determinados fragmentos de Variedades (2007), de Paul Valéry, para justamente explorarmos este assunto tão caro ao poeta-crítico francês: a poética da voz.

Como os títulos dos poemas sugerem, a questão das origens do ser - sujeito, mundo e linguagem - espraiam-se em seus versos, de maneira a dialogar irremediavelmente com o discurso da gênese bíblica. A temática do nascedouro de mundos e formas de pensamento (abrangendo-se aqui a linguagem poética) delineia-se no arcabouço estrutural dos textos, na medida em que "Gênesis" e "Antigênesis" agenciam suas perscrutações temáticas através (porque atravessam mesmo) da forma escritural do poema, gênero que, de acordo com Meschonnic (2006, p. 6), "é uma crítica da linguagem", por devassar suas origens, operando em seu âmago e tornando o que se considera, na "linguagem ordinária", como "desvio", a força motriz de sua criação. Assim, o que era "desvio" transforma-se em norma crítico-poética; regulamentação ontológica que permite, no plano de escritura, a inscrição subjetiva de uma voz e, principalmente, de um ritmo emancipadores e gerenciadores do próprio pensar e sentir: "se a poesia é a revelação do ritmo como tal, como o rio da linguagem com que, momentaneamente, um sujeito se identifica, a poesia faz essa noção de linguagem ordinária voltar-se contra si mesma" (Meschonnic, 2006, p. 14).

Conforme destaca Meschonnic (2006, p. 16, grifo nosso), “o estatuto do poema age como um revelador do estatuto da linguagem, e do sujeito, tanto nas sociedades quanto na filosofia e nas ciências da sociedade". Além disso, Henri Meschonnic aponta para a necessidade de discernir certo aceno, ou gesto do "oral"3 (conceito que o teórico e tradutor francês diferencia do "falado") nos poemas, de forma que se reconheça a oralidade como um verdadeiro método discursivo orquestrado pelo ritmo expresso na escrita. Em outras palavras, é por meio da escritura, ${ }^{4}$ sobretudo poética, que a voz se incorpora, agasalhada pelo ritmo que é "a manifestação de um gestual, de uma corporeidade e de uma subjetividade na linguagem. Com os recursos do falado no falado. Com os recursos do escrito no escrito. E se alguma coisa mostra que há oral no escrito, e que o oral não é o falado, é exatamente a literatura" (Meschonnic, 2006, p. 18).

O ritmo simula a ciranda constelar em que, paradoxalmente, a voz se dinamiza na escritura de maneira a potencializar o movimento em sístole-diástole cósmicas performatizadas na criação poético-ontológica dos textos. É o ritmo, pois, o agente do sopro vital dos poemas, influxo em que se insinua corporeamente a subjetividade lírica insuflada explícita ou implicitamente verso a verso - seja pela voz, seja pelo silêncio, que não deixa de ser uma inscrição dessa voz.

Sendo assim, a observação de uma poética da voz faz-se não só interessante, mas também necessária para compreendermos como se dão seus movimentos nos poemas e de que maneira essa "forma de vida" se configura como um eixo central para a leitura e fruição dos textos poéticos. Questão nuclear nos estudos de Paul Valéry, a voz é estudada a partir da perspectiva da escrita, ou sobre como as composições escritas fomentam a elaboração de uma espécie de "voz encarnada na própria voz", haja vista que:

\footnotetext{
${ }^{2}$ Os trabalhos sobre o tema do silêncio na obra poética de Orides Fontela são vários. Destacamos, a título de ilustração, o ensaio de Marcos Lopes, intitulado "O canto e o silêncio na poética de Orides Fontela" (2008), em que o autor realiza incursões de cunho filosófico em alguns poemas, tais como "As sereias" (publicado em Helianto, de 1973), explorando o canto e o silêncio à luz dos comentários de M. Blanchot, no momento em que, no Livro por vir, o teórico analisa o conto "O silêncio das sereias", de Kafka

${ }^{3}$ Meschonnic defende a ideia de que a oposição entre o "falado" (confundindo-se ao "oral") e o "escrito" teria como base interpretativa a dicotomia do signo, tradicionalmente cindido em "significante" e "significado". Contudo, o teórico francês apregoa a necessidade de se entender, na verdade, uma espécie de tripartição entre as instâncias da oralidade (disseminada pelo ritmo e, de certa forma, pelo movimento performático de enunciação e de leitura), do escrito e do falado. Para tanto, o autor afirma que: "O oral seria o conjunto dos modos de significar caracterizados por esta transformação. Seu índice. Tanto no escrito quanto no falado. Há uma voz da oralidade no falado. Assim como não se tem a mesma voz lendo e falando. Não há oralidade sem sujeito nem sujeito sem oralidade. Um contínuo do sujeito, desde aquele do discurso, no sentido de Benveniste, até o do poema. O oral é da ordem do contínuo - ritmo, prosódia, enunciação. O falado e o escrito são da ordem do descontínuo, das unidades discretas da língua” (2006, p. 42).

${ }^{4}$ Segundo Meschonnic (2006, p. 7): “A escritura, paradoxalmente, é a melhor ilustração da oralidade. Sua realização por excelência. Elas não se compreendem melhor isoladamente do que uma através da outra".
} 
um poema sobre o papel não é nada além de uma escrita submetida a tudo que se pode fazer de uma escrita. Mas, entre todas as possiblidades, existe uma, e apenas uma, que coloca enfim esse texto sob as condições em que ele tomará força e forma de ação. Um poema é um discurso que exige e que engendra uma ligação contínua entre a voz que existe e a voz que vem e deve vir. E essa voz deve ser tal que ela se imponha e que ela excite o estado afetivo do qual o texto seja a única expressão verbal. Retirem a voz e a voz que é necessária, e tudo se torna arbitrário. O poema se transforma em uma sequência de signos que não encontram ligação além do fato de estarem materialmente traçados uns depois dos outros (Valéry, 2007, p. 185-186).

Tal como percebemos nas considerações de Meschonnic, parece-nos que Valéry também confirma que, nas idas e vindas da potência escritural, a construção de uma voz se perfaz. Seria, portanto, por meio do atravessamento da voz na escritura, que os poemas ganhariam "força e forma de ação". A partir da ideia de que o poema se realiza por meio "da voz que existe e a voz que vem e deve vir", Valéry indica a possibilidade de existir um tipo de contradição (e, por que não, contradicção) intrínseca ao "eu", fenômeno que concretizaria a construção de uma voz outra, interior ao sujeito.

Haveria, portanto, a necessidade de se pôr à escuta dessa nova voz, posto que essa se transubstancia em "voz-pensamento", que agencia também a "linguagem-pensamento" instituída no texto poético. Em outras palavras, é como se um amálgama de voz/escuta insurgisse a fim de que o plano semântico dos poemas, de seus sentidos (encrustados nos signos) e de sua significação (disseminada na presença do corpo rítmico) sobredeterminassem uma lógica diversa de criação e apropriação das formas poéticas, de maneira que a experimentação do sensível, amparada pela escuta da "voz da voz" do "eu", propiciasse também uma espécie de "pensamento auditivo" vibrátil, que atravessa o corpo e que permite à voz ser pensada com e pelo corpo do sujeito e do poema, ou, quem sabe, de um sujeito-corpopoema, formalizado, enfim, por seu destino poético-ontológico.

Há, contudo, no estatuto dessa voz interior, um silêncio ou, ao menos, um ponto em que não se ouve. Valéry apresenta a possibilidade de, pelas vias do poético, reaprendermos a escutar essa conjuntura inaudível, para que, por meio dela, possamos ouvir a enigmática voz interior que nos habita e deságua na criação poética. Essa voz que irrompe a partir da leitura e da escuta nos seduz, impelindo-nos a contemplar não um canto explicitado, mas o silêncio interdito das sereias que fiam um devir abissal.

Tendo como ponto de partida as reflexões de Meschonnic e de Valéry no que respeita à construção poético-ontológica do poema, em que o ritmo se inscreve tanto como elemento da voz quanto da escritura e que, devido a isto, performa a inscrição de uma semântica (em que forma e conteúdo não se dissociam, mas operam conjuntamente), bem como de um sujeito, fazse interessante apreciarmos os poemas de Orides Fontela:

Gênesis

Um pássaro arcaico

(com sabor de

origem)

pairou (pássaro arcano) sobre os mares.

Um pássaro

movendo-se

espelhando-se

em águas plenas, desvelou

o sangue.

Um pássaro silente

abriu

as

asas 
- plenas de luz profunda -

sobre as águas.

Um pássaro

invocou mudamente

o abismo.

(Fontela, 2015, p. 147)

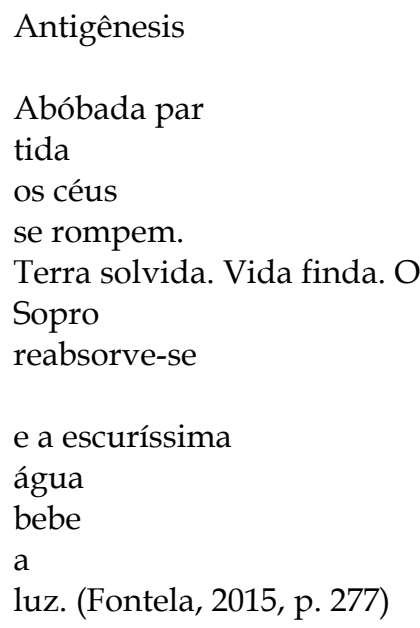

Conforme já indiciávamos anteriormente, "Gênesis" e "Antigênesis" estabelecem diálogo com a narrativa de origem bíblica e seu primeiro livro, Gênesis. De acordo com a Bíblia de Jerusalém (Gn, 1, 1-3, grifo nosso): "1. No princípio, Deus criou o céu e a terra. 2. Ora, a terra estava vazia e vaga, as trevas cobriam o abismo, e um sopro de Deus agitava a superfície das águas."

Parece-nos, no entanto, que ambos os poemas, à sua maneira, subvertem tematicamente o texto original. $O$ segundo apresenta-se, na verdade, como subversão de nível inter e intratextual, uma vez que a relação com o texto bíblico resiste, como também permanece o vínculo com o primeiro poema escrito por Orides.

De qualquer forma, a "gênesis" a ser arquitetada ou desfeita revela uma voz singular, em que o sujeito da elocução, contraditoriamente - caso coloquemos em oposição a sua voz àquela onipotente, da divindade -, desaparece. ${ }^{5}$ A essa nova narrativa "liricamente originária" do mundo, alia-se à presença paradoxal de uma voz que cala e, diferentemente do texto original, não inaugura o mundo com as palavras incandescentes do fiat lux divino, mas com o gesto silente de um pássaro (ou de seu lastro, a luz que carrega em suas asas) que abjura sua natureza órfica (porque não canta) e segue seu voo cosmogônico inaugural, seja para criar, seja para erradicar mundos.

Refletindo sobre o poema "Gênesis", vislumbramos a imagem do pássaro (mais um vínculo com a narrativa-fonte, se pensarmos na figuração do espírito primordial e sagrado metamorfoseado em pomba) que remete às origens, porque este pássaro é, antes de tudo, "arcaico" (verso 1), dotado de um "sabor de / origem" (versos 2 e 3), o que não deixa de ser também um tipo de "saber" original e originário. É esta figura o agente das ações no poema, a maioria registrada com o uso do pretérito perfeito do indicativo (tornando-se "perfeitas" por aludirem a um tempo que se inicia e se encerra no passado): "pairou" (verso 4), "desvelou"(verso 9), "abriu" (verso 12) e "invocou" (verso 18). Cada uma dessas ações se inscreve solitária, no interior das 4 estrofes que compõem o poema, com exceção de "desvelou", prática acompanhada por outros dois verbos "movendo" (verso 7) e "espelhando" (verso 8), registrados na forma nominal do gerúndio e que, talvez por isso mesmo, funcionam muito mais

\footnotetext{
${ }^{5}$ A desaparição elocutória do sujeito lírico não é novidade e remonta a certa "tradição da modernidade" representada, por exemplo, pelo fazer poético de Mallarmé.
} 
como ações que se emprestam à substância do ser-pássaro, suspenso temporariamente em um "eterno-instante-já", paradoxalmente temporário, que prefigura e fundamenta a próxima ação "perfeita" a seguir. A criatura arcaica desvela o sangue, matéria-prima a construir o pré-mundo que guarda e, em certa medida, ajuda a edificar. Tais ações "perfeitas" do pássaro revelam uma sequência interessante, caso as relacionemos à temática de um princípio criativo de mundos.

Em um primeiro momento, a ave muda e repleta de luz (aspectos que a aproximam e a distanciam, concomitantemente, do ser divino da "Gênesis" original) paira sobre as águas, assim como faz o "sopro de Deus" (que simula o espírito e anuncia o poder de fala da divindade, agitando-se para anunciar "haja luz"). Contudo, em divergência ao texto original, a entidade alada do poema de Orides Fontela não agencia uma potência criadora de mundos $a$ priori. Apenas paira sobre um mundo parcialmente já determinado (e relativamente estruturado, que apresenta mares, por exemplo), ainda que não haja indícios de seu demiurgo.

Já na segunda estrofe, o pássaro dinamiza seus movimentos (antes pairava) sobre um oceano primevo. Espelha-se (em um plano de inversão, já que seriam as águas os agentes capazes de espelhar algo), realizando o início de um fluxo vital, mimeticamente emanado nas águas que recebem seu reflexo. A ave, a essa altura, revela o sangue (ou sua natureza em contraposição à "graça" divina) que a fundamenta, sangue esse que será a base genesíaca de uma nova totalidade, de certa forma apartada daquela em que a voz divina onipotente vigora. $\mathrm{O}$ empenho de seu corpo, entretanto, é o que ganhará destaque em todas as estrofes do poema. O pássaro move-se, espelha-se; mimetiza suas ações, reorientando a construção de uma narrativa de origem diversa e essencialmente poética, visto que se baseia, para além de uma ação inaugural, em um ato infinito (de certa forma, também reiterado em todo início de estrofe, em que a expressão "um pássaro" aparece, com pequenas mas importantes variações, como se se tratasse de uma estrutura paralelística, dotada de refrão), quase fadado a uma repetição de sabor mítico.

$\mathrm{Na}$ terceira estrofe, o pássaro ganha o atributo que já se insinuava nas anteriores: o silêncio. Silente, a ave abre suas asas incandescentes sobre as águas. Para além disso, o preciso corte sintático, viabilizado pelos enjambements, trama um tipo de suspense que, no corpo do poema, manifestará a potência icônica da ave com as asas abertas (amparada pelos travessões que isolam a visão do voo e aludem ao gesto do animal, no verso 15: " - plenas de luz profunda -"), pairando novamente sobre as águas, em suspenso. Nesse momento, a aparente ausência de voz, pensada inicialmente como um mero apagamento "fônico" da vocalização do pássaro não é, de forma alguma, ausência real da voz.

O que vislumbramos nessa estrofe, assim como nas anteriores, se não se trata da vocalização da ave, transubstancia-se numa espécie de voz anterior do sujeito lírico "desaparecido" no plano da elocução (como a entidade demiúrgica "tradicional" ausente no projeto de criação deste mundo). Colocando em outros termos, é como se a subjetividade lírica saltasse do esboço elocutório do poema, numa atitude que a aproximaria da alteridade, a fim de justamente encontrar, no "ponto surdo" de sua voz, pondo-se à escuta do outro (ainda que o outro também esteja mudo, se pensarmos na figuração do pássaro-deus delineada, podendo ser uma espécie de alter do "eu"), à presença de outra voz. Mas essa voz não vem senão pelo sopro involuntário (ao acaso), pelo arfar das asas do pássaro que, exatamente por não cantar, inaugura mundos e (per)versamente (pelos próprios versos), invoca abismos.

A formulação ontológica em "Gênesis" não poderia ser rascunhada de outra forma, senão pelas vias da escritura poética. Precisamos, finalmente, "pensar com o ouvido" e, por meio da crítica à "linguagem ordinária" natural e genuinamente estabelecida no poema, reconfigurar nossos modos de pensar, como leitores, a própria linguagem, convite que se estende também a repensarmos nossa própria existência. É nesse sentido que o "desvio" se torna regra: quando o ritmo não é apenas significação (o que já não seria pouco), mas procedimento de construção para a obra artística.

Pensando no ritmo como um "fundador de mundos", a partir da perspectiva poética, a vozoutra que se entrevê no poema "Gênesis" precisa ser, de fato, "notada" a partir de um tipo de partitura secreta que se entretece entre "a voz que vem e deve vir", aludindo, mais uma vez, a Valéry. De acordo com Meschonnic (2006, p. 39), "a voz é invisível, o ritmo é invisível, mas eles 
pedem uma visualização, uma notação". Assim sendo, uma das maneiras possíveis de "ver" e de sentir o ritmo é emprestarmos nosso ouvido à lógica criativa que reflui no poema. Perceber o sopro amalgamado à figura do pássaro silente é, talvez, inferir que a voz-outra, voz-silêncio da ave, seja exatamente a solicitude de seu corpo, provocadora de outro extraordinário tipo de "vocalização" (entendendo-se aqui como presença de voz, não apenas no nível fônico) ou, pensando nos termos de Meschonnic, de oralidade. É assim que o silêncio vira voz mediada pelo senso rítmico modulado nos versos. A performance suave do voo revela, amparada pela permanência dos fonemas nasais, tal como podemos observar em "origem" (verso 3), "arcano" (verso 4), "mares" (verso 5), "movendo-se" (verso 7), "espelhando-se"(verso 8), "plenas" (verso 9 e 15), "sangue" (verso 10), "silente" (verso 11), "profunda" (verso 15), "invocou" e "mudamente" (verso 18), a suspensão do canto da ave. Contudo, é exatamente isso que, paradoxalmente, desfia-se no corpo do poema: (anti)ode original e originária, tecida a partir de um canto silente.

Meschonnic, ao estudar o ritmo como manancial de significação e de inscrição do sujeito, incluído em uma historicidade, afirma que:

Para precisar o que podem ser tais laços, não há, provavelmente, melhor meio que a análise do ritmo e da prosódia como subjetividade-especificidade-historicidade. O que dizia Mallarmé a Verlaine quando escrevia para ele: "Você tem sua sintaxe". Nessas simples palavras, tudo está dito (Meschonnic, 2006, p. 11).

O tradutor francês evidencia que a escritura poética promove singularmente sua própria organização das funções dos termos sintáticos, redefinindo, pelo arranjo sintagmático, seu modo de existência. Além disso, "ter sua própria sintaxe" pode significar ter seus próprios meios rítmicos (gestualidade, entonação e corporeidade particulares) de entender-se e de se relacionar com o mundo.

No poema "Gênesis", o rearranjo semântico propiciado pelo ritmo, para além das modulações sonoras, realiza-se no corte sintático vinculado aos inúmeros enjambements. Esses cortes, aliados aos "sopros" de ordem sonora, criam as imagens poéticas que saltam, tal como a subjetividade lírica que "escapa", verso a verso. A experiência de leitura nos leva à audiçãovisão de uma sequência de quadros liricamente fotografados, dos quais, aparentemente, temos acesso apenas aos flashes das luzes (que descobrem o pássaro, também pura luz) que ressoam sinestésica e perturbadoramente a cada "clique", em meio à escuridão primordial.

É na quarta estrofe que o mistério da origem se intensifica. O pássaro invoca o abismo. A última ação "perfeita" do poema: invocar. A ave cósmica incita a retroconstrução semântica desse verbo. Invocar pode significar chamar em auxílio, pedir a proteção de alguém ou de algo, recorrer a, ajudar a, mas também evocar (quaisquer formas e forças sobrenaturais), assim como causar irritação, provocar, intrigar, ou ainda, alegar a favor de alguém ou de algo. Pelo o que percebemos, o signo "invocar" é repleto de sentidos. Mas qual deles poderia se inclinar à significação do poema? Ao invocar o abismo, o pássaro-origem de Orides Fontela decanta cada um dos sentidos do verbo e, sem dizer palavra alguma, incorpora-os todos em si e em sua performance de voo cósmica: pássaro-legião.

Talvez esteja aí a "gênesis" em questão: sentir, pensar-ouvir uma voz que se cala; incluir o outro (ou a "voz da voz", a "voz-silêncio"), mesmo que isso signifique saltar no abismo, algo que não deixa de ser o destino ontológico de toda escritura poética, tal como sugere Agamben (2002) em "O fim do poema". Nesse ensaio, o filósofo parte da premissa de que o poema é uma "hesitação prolongada entre som e sentido", referindo-se a Valéry para defender a tese de que o fazer poético (e principalmente sua crítica) deve superar a dicotomia semiótica versus semântica. Para tanto, Agamben usa a metáfora da queda, do salto ao infinito, que todo poema opera quando parece chegar ao fim, ao simular também pequenos outros saltos, empreendidos pelos enjambements, elementos característicos do texto poético, uma vez que:

A dupla intensidade que anima a língua não se aplaca numa compreensão última, mas se abisma, por assim dizer, no silêncio numa queda sem fim. Deste modo o poema desvela o escopo da sua orgulhosa estratégia: que a língua consiga no fim comunicar ela própria, sem restar não dita naquilo que diz (Agamben, 2002, p. 147-148). 
Se a construção do poema "Gênesis" é problemática no momento em que é comparada ao "discurso oficial bíblico", trata-se também de um tipo notável de invocação do leitor, fazendo-o encontrar outro paradigma original de leitura. O mesmo acontece com "Antigênesis", do livro Rosácea, publicado em 1986, que estabelece diálogo tanto com a Gênesis bíblica, quanto com o poema homônimo da obra Helianto, de 1973.

"Antigênesis", como o próprio título sugere, versa sobre a desagregação genesíaca. Mais conciso que o poema anterior, a desconstrução cósmica se "anuncia" em apenas duas estrofes. A fissura sintático-semântica, que parte o enigmático mundo arquitetado em "Gênesis", cinde também "Antigênesis", potencializando, neste poema, o recurso já anteriormente observado no outro: o enjambement. Aqui, não apenas os sintagmas se partem, como também os próprios signos: "Abóbada par/ tida" (versos 1 e 2), prenunciando a ruína cósmica.

A primeira estrofe plasma, como um quadro de intuição apocalíptica, a queda do firmamento; a esfera que o sustentava se rompe dramaticamente. A abóbada celeste carrega sua destruição consigo, encaminhando-a até a "Terra solvida" (verso 5), que, tornando-se pura diluição, não pode mais sustentar qualquer tipo de vida. Apesar da imagem do pássaro aparentemente perder-se, uma vez que sua figuratização representaria a vida impossível neste novo poema, suspeitamos que sua presença regressa indicialmente diluída ("solvida") na própria palavra que também pode se romper, prenhe de outros significados e de outros vocábulos, tais como "sol/vida". Se assim for, a vida estaria paradoxalmente "finda" (verso 5), devido ao próprio excesso de luz estelar que, ao descer dos céus, destrói a possibilidade de existência conhecida.

Além disso, se o pássaro se insinuava pelo esplendor de seu voo no primeiro poema, haveria outro índice de sua existência rarefeita no segundo. Explicamos: entendemos, a partir da leitura de "Gênesis", que o sopro no canto ausente da ave se dava, corporeamente silencioso, pelo arfar de suas asas em amplo dinamismo. Seria devido ao efeito de visão-escuta (de cunho afetivo e reflexivo, o que não deixa de ser também criativo), portanto, que divisávamos a possibilidade de situarmo-nos, enquanto leitores, no "ponto surdo" do poema, para que fosse possível ouvirmos a voz-outra, da mesma forma que a subjetividade lírica, ao desvencilhar-se de si, abrindo o seu campo de visão ao protagonismo do pássaro-origem, também ouviria uma espécie de eco da voz de sua voz.

Ocorre que, mesmo que exista essa tênue relação entre as figuras que habitam um poema e outro, a potência criativa se transforma. Há, em "Antigênesis", a presença do sopro (em diálogo explícito com a narrativa-fonte). Tal imagem, contudo, não estimula a criação, a expansão do mundo primal tangenciado. O que se percebe é o movimento de interiorização do "Sopro" (verso 6) que "reabsorve-se" (verso 7). Se o sopro de vida no primeiro poema agenciava, ainda que insondavelmente, uma dinâmica de construção, de abertura e expiração do universo que se compunha, agora o gesto é inverso: promove a inspiração, o alheamento mais profundo deste mundo que desmorona antes mesmo de completar-se. Sua derrocada assemelha-se à movimentação cósmica causada pelos buracos negros (que, aliás, despertam, em certa medida, na imagem da "escuríssima água" presente na próxima estrofe): sugam todos os corpos celestes, apagando até mesmo o brilho da luz. A entidade "Sopro" retroalimenta-se, serpenteando sua dança cósmica de criação e destruição, magistralmente decantada na sequência dos fonemas "sibilantes" (/s/) de "O / Sopro / reabsorve-se", mantendo o vínculo sonoro com o vocábulo "escuríssima" (atributo da água que apaga toda a luz, na última estrofe e que se aproxima analogicamente ao sangue desvelado no poema anterior). Assim, o sopro vital nega-se ao ser vivente. E o profano se divisa, antepondo-se ao divino: a serpente-sopro, sibilante e inaudita, morde a própria cauda e rompe a veia dos céus.

A última estrofe, tão esfíngica quanto a derradeira estrofe do primeiro poema (“Um pássaro / invocou mudamente / o abismo"), mantém, por meio da analogia, relação com a primeira de "Antigênesis", posto que a imagem da "terra solvida" emerge na potência imagética da "escuríssima / água" (versos 8 e 9) que "bebe / a / luz" (versos 10, 11 e 12). Nesses últimos versos, estranhamente a ideia de destruição se esvai, dada a cadência rítmica gerenciada pelos cortes sintáticos. É como se voltássemos ao "instante quase-um" do mundo, momento em que o cosmos 
está por fazer-se. A "Antigênesis" não seria, destarte, propriamente o fim, mas o retorno a um tempo anterior às origens, ou ainda, a um tempo em que mesmo a "gênesis" é da ordem do porvir (em que o prefixo "anti", para além de uma oposição carregue também o "antes"). É dessa forma, talvez, que a escuríssima água beba a luz. Ao absorvê-la, assim como o "Sopro" reabsorve-se, uma espécie de vida anterior ou interior à vida, ou uma voz interior à própria voz insurge.

Dessa maneira, ao "(re)absorver-se", o "Sopro" repete uma ação que desestrutura a criação genesíaca, como se estivesse fadado a tramar e destramar mundos, a partir de sua vitalidade primordial. Nesse sentido, o sopro-voz, já não mais mero ruído, ainda não palavra instituída, alia-se ao tema de ambos os poemas de forma a explorar, na carne da linguagem, a natureza ontológica e originária própria da poesia. Trata-se de um ritmo singular, atravessado por um som que, ao hesitar entre o si e o signo, é capaz de gerar a escritura poética e mais: tornar este ato de criação, mas também de leitura, infinito. ${ }^{6}$

\section{Referências}

AGAMBEN, Giorgio (2002). O fim do poema. Tradução de Sérgio Alcides. Cacto, São Paulo, n. 1, ago. BÍBLIA (2006). Bíblia de Jerusalém. São Paulo: Paulus.

FONTELA, Orides (2015). Poesia completa. Organização de Luís Dolhnikoff. São Paulo: Hedra.

LOPES, Marcos Aparecido (2008). O canto e o silêncio na poética de Orides Fontela. Ipotesi, Juiz de Fora, v. 12, jul./dez.

MESCHONNIC, Henri (2006). Linguagem ritmo e vida. Tradução de Cristiano Florentino. Belo Horizonte: Fale/UFMG.

VALÉRY, Paul (2007). Variedades. Tradução de Maiza Martins de Siqueira. São Paulo: Iluminuras.

\footnotetext{
${ }^{6}$ Valéry (2007, p. 200), no texto "Poesia e pensamento abstrato", de Variedades, reflete: "Coisa estranha: o som e como que a imagem de sua pequena frase reaparecem em mim, repetem-se em mim, como se estivessem se divertindo em mim; e eu gosto de me escutar repetindo-a, repetindo essa pequena frase que quase perdeu o sentido, que deixou de servir e que, no entanto, quer viver ainda, mas de uma vida totalmente diferente. Ela adquiriu um valor; e adquiriu-o em detrimento de seu significado finito. Criou a necessidade de ser ouvida ainda... Eis-nos às próprias margens do estado de poesia. Essa experiência minúscula nos bastará para descobrir muitas verdades".
} 